\title{
Strange Bedfellows: Why France's Emmanuel Macron and His Autocratic Friends Are Attempting to Impose Another Strongman in the MENA Region
}

\author{
TIMOTHY REID \\ Former Senior Defense Reform Adviser \\ United Nations Support Mission in Libya \\ ORCID No: 0000-0002-2748-5736
}

ABSTRACT France has lately edged ever closer to a number of autocracies in Africa and the Middle East. Notably, in the name of combating "Islamic terrorism" - which it links to "political Islam"- it has actively supported Libyan warlord Khalifa Haftar. While actively allying with the United Arab Emirates (UAE), Egypt, and Saudi Arabia; it has aggressively confronted Turkey and undermined the internationally recognized Libyan Government of National Accord (GNA). In doing so, France finds itself in the same camp as Russian and Janjaweed mercenaries. Since France, in theory, supports the GNA and since Turkey has been sheltering millions of refugees that otherwise would flood Europe, this hostility is hard to comprehend. The present commentary will seek to examine the premises of this policy and what may be behind its actions.

Keywords: Libya, France, Haftar, UAE, Saudi Arabia, Egypt, Turkey, Arms Sales, Refugees, Feminist Foreign Policy 
Introduction: The Legacy of Muammar Qaddafi and the Damage Done by His Would-be Successor

Muammar Qaddafi ruled Libya (badly) with an iron fist for 42 years, creating a grotesque system of governance that combined personality cult, Islam, and communist political structures. The result was a degradation of good citizenship and rotten institutions -especially the security services. Despite the nostalgia that French Foreign Minister Jean-Yves Le Drian has for Qaddafi, ${ }^{1}$ globalization and advances in communication meant it was inevitable that Libyans, fed up with his 42 years of brutality and oppression, ${ }^{2}$ would rise up. When Qaddafi launched a campaign to slaughter the people of Benghazi, it was France under President Nicholas Sarkozy -despite his previous insouciance and economic interests- who took the first concrete steps to stop it. ${ }^{3}$ Libyan appreciation for France's role was evident in the large notice board that greeted travelers arriving at Benghazi airport.

Unfortunately, as then U.S. President Barack Obama ${ }^{4}$ and the UK House of Commons Foreign Affairs Committee ${ }^{5}$ noted, the international community failed to appreciate the urgency of Libya's plight and allocate the necessary resources to bring stability to Libya after the Revolution and the situation deteriorated.

Khalifa Haftar was an officer in King Idris' army and had been a commander under Qaddafi from the time he seized power in 1969. After Haftar was defeated by French forces in Chad in 1989, Qaddafi disowned him and he was taken over by the Central Intelligence Agency (CIA) as an agent in their conflict with Qaddafi. ${ }^{6}$ Returning from exile in the United States in 2011, he wanted to command the revolutionary forces, but could only get Commander of the land forces ${ }^{7}$ (effectively the third highest post). In February 2014, he called for suspension of the General National Congress and the government in a failed coup attempt. ${ }^{8} \mathrm{He}$ then led a coalition of army units, former revolutionary groups and tribal militias calling themselves the "Libyan National Army" (LNA) in a series of attacks, presented as Operation Karama (Dignity), against not only the radical group Ansar al-Sharia in Benghazi but also officially recognized units, funded and nominally under the command of the Chief of General Staff. While claiming to serve the government based in Tobruk, Haftar has established a kind of military mini-state where he is the supreme authority and where rights and freedoms have gradually diminished.

With the Libyan Political Agreement negotiated by the UN on December 17, 2015, a Government of National Accord (GNA) was formed, recognized by the entire international community including all of the permanent members of the UN Security Council and the countries of the Middle East and North Africa (MENA). Haftar did everything he could to prevent its implementation. The chaos that followed gave the so- 
called "Islamic State of Iraq and Syria (ISIS)" 10 an opportunity to gain a foothold, especially in Sirte. ${ }^{11}$ Haftar defeated the extremist group Ansar al-Sharia in Benghazi, while destroying much of the city. He used this as his calling card to portray himself the "great fighter of the Islamic terrorists," 12 yet others fought the greatest battles. Local Salafists drove ISIS from Derna in $2015^{13}$ and then routed it from Sabratha along with other anti-Haftar elements and the help of U.S. airstrikes. ${ }^{14}$ The battle for Sirte was won by the GNA's Bunyan Marsous ("Solid Wall") operation -composed mainly of fighters from Misrata and small contingents from other towns - supported by U.S. and UK intelligence and logistics, ${ }^{15}$ special forces and air support. ${ }^{16}$ Six hundred and fifty GNA fighters gave their lives and 2,000 were wounded. ${ }^{17}$ While GNA forces fought ISIS, Haftar took control of the oil fields and bought the loyalty of certain tribal militias in the south. The United Nations Support Mission in Libya (UNSMIL) continued to mediate and a national conference was scheduled for April 2019. ${ }^{18}$ A few days before it was to start, Haftar launched a major offensive on Tripoli. One year later, UNSMIL described the impact of this offensive: ${ }^{19}$

\section{Humanitarian Situation Deteriorated to Unprecedented Levels}

- At least 685 civilian casualties (356 deaths and 329 injured)

- 149,000 people in and around Tripoli forced to flee their homes

\section{Macron and Le Drian have}

taken up with some odd

bedfellows, starting with the

regional autocracies: Saudi

Arabia, Egypt and the UAE.

They seem an odd fit with

Macron's supposed "feminist

foreign policy"

- Over 345,000 civilians remain in frontline areas

- Additional 749,000 people in areas affected by the clashes

- 893,000 people in need of humanitarian assistance

- Appalling impact in terms of damage to and destruction of homes, hospitals, schools and detention facilities

- Human rights violations have exponentially increased with attacks against human rights defenders and journalists, doctors, lawyers and judges, migrants and refugees, and deteriorating conditions of detention.

\section{Economic Collapse}

- Over 100 billion Libyan Dinars (LYD) in domestically held debt (\$73.4 billion)

- Another \$1 billion credit lines for domestic fuel imports

- LYD 169 billion (\$124.1 billion) outstanding contractual obligations 


\section{Sheikh al-Madkhali is strongly}

opposed to the Muslim

Brotherhood. Many of Haftar's

Libyan fighters subscribe

to this doctrine and have

a history of enforcing ever

stricter social mores when

they take over a region
- Oil blockade imposed January 17, 2020 already resulted in financial losses exceeding $\$ 4$ billion

- Spending diverted to war effort destroying rather than building critical infrastructure

- Two separate central banks prevented monetary or fiscal policy reform and contributed to a domestic banking crisis.

All of the above problems have been compounded by the COVID-19 pandemic. ${ }^{20}$

Haftar's French-backed campaign caused more hardships for women and children, as well as a higher likelihood of sexual violence. ${ }^{21}$ Member of Parliament Siham Sergewa was kidnapped from her home in Benghazi by an armed group ${ }^{22}$ and we still have no news of her fate. ${ }^{23} \mathrm{On}$ April 27, 2020 -following another 248 civilian casualties largely due to his forces- Haftar claimed to have a mandate to take over all government in Libya, removing whatever small legitimacy he had claimed from his association with the House of Representatives. ${ }^{24}$

\section{The Friends of Haftar Club}

The Macron government appears to have a fear of Islam. It recently instigated a controversial campaign at home against "Islamic separatism.". 25 Nonetheless, in their foreign campaign against "Islamic terrorism"26 and "political Islam," ${ }^{27}$ Macron and Le Drian have taken up with some odd bedfellows, starting with the regional autocracies: Saudi Arabia, Egypt, and the UAE. ${ }^{28}$ They seem an odd fit with Macron's supposed "feminist foreign policy."

\section{Saudi Arabia}

Under Crown Prince Mohammed Bin Salman, Saudi Arabia has gone from being a calming force in the region to a destabilizer. Its legal system is based on Sharia law. In 2018, the regime murdered a journalist abroad ${ }^{29}$ and has developed a very bad reputation for human rights, ${ }^{30}$ despite expensive efforts to whitewash its reputation. ${ }^{31}$ Saudi interests have bought into newspapers owned by Russian oligarch and former $\mathrm{KGB}^{32}$ officer $\mathrm{Al}$ exander Lebedev and his son Evgeny, which include the London Evening Standard and the Independent. ${ }^{33} \mathrm{Al}-$ exander is sometimes critical of the Russian government but has also provided support for controversial moves like the annexation of Crimea. ${ }^{34}$ Women are required to cover themselves completely. Despite now having the right to drive, those who had petitioned for this right have gone to 

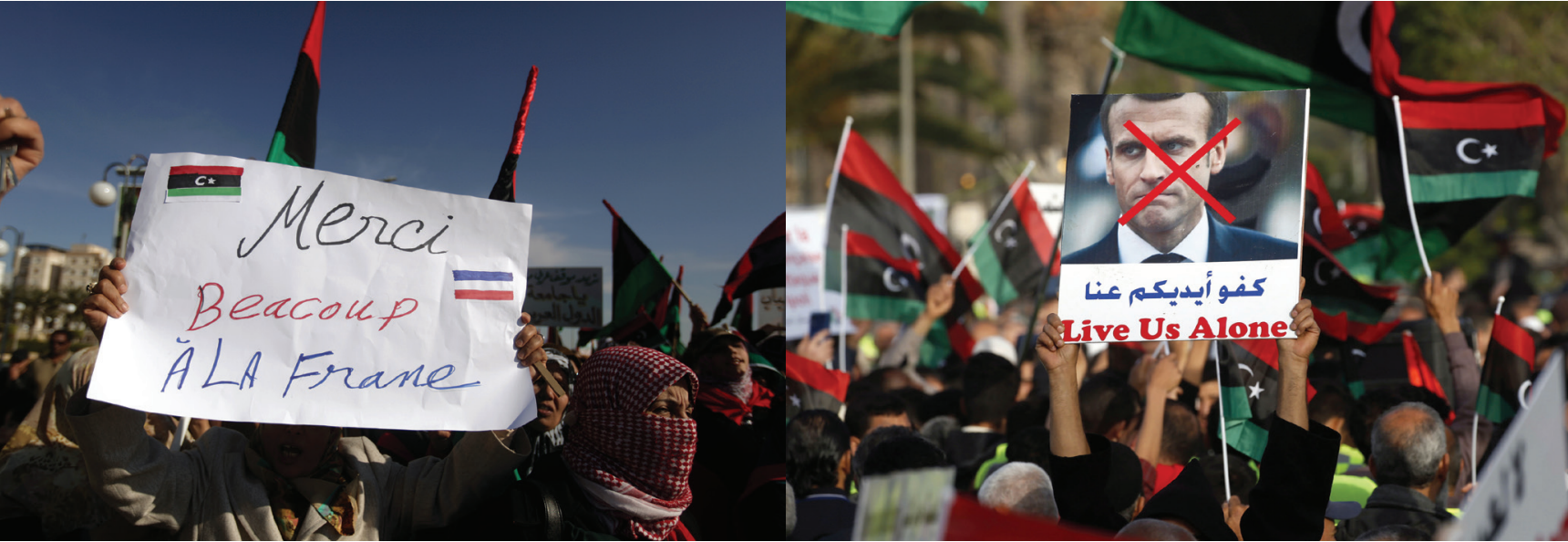

jail, including a royal princess. ${ }^{35}$ In protest of Saudi Arabia's treatment of women and other human rights abuses, activists have discouraged governments from attending a November 2020 G20 summit hosted by Saudi Arabia. ${ }^{36}$ Following the problems caused by al-Qaida ${ }^{37}$ abroad and at home, some of the country's leadership started supporting a different strain of conservative (quietist) Sunni Islam with less potential to be a threat to the regime than the classic Wahabi school. One of Saudi Arabia's main contributions to Haftar has been the ideological support of the Madkhali Salafists. ${ }^{38}$ While still preaching extremely conservative Islam, this line of thought also says not to question secular leaders, a very convenient notion for princes and strongmen.

Sheikh al-Madkhali is strongly opposed to the Muslim Brotherhood. ${ }^{39}$ Many of Haftar's Libyan fighters subscribe to this doctrine and have a history of enforcing ever stricter social mores when they take over a region. ${ }^{40}$
They also have followers among the GNA, causing some to fear a " 5 th $\mathrm{Col}$ umn" that could join Haftar or form another ultra-conservative regime. ${ }^{41}$ Besides ideology, Saudi Arabia has helped Haftar by lobbying Washington, ${ }^{42}$ financing, ${ }^{43}$ and possibly paying for Russian mercenaries. ${ }^{44}$ Both the U.S. Congress ${ }^{45}$ and the European Parliament have pushed to block arms sales to the Kingdom. ${ }^{46}$ In 2019, a UK Court of Appeal ruled arms sales to Saudi Arabia illegal because the British Government had not adequately considered accusations of violations of international humanitarian law. ${ }^{47}$ As the UK seeks to renew sales, activists are again taking the case to court. ${ }^{48}$

\section{The UAE}

The UAE is Saudi Arabia's main ally in the brutal Yemen conflict that has displaced 6.65 million and put 24.3 million people in need. ${ }^{49}$ Though more modern than Saudi Arabia, Sharia remains an important source of law. For example, women who
A woman holds a placard reading in French"Thank you very much France" during a rally calling for the imposition of a no-fly zone in Benghazi in Eastern Libya on March 12, 2011. By contrast 8 years later in Western Libya, a message rejecting French President

Macron is

displayed during a demonstration with yellow vests against strongman Khalifa Haftar in Tripoli on April 19, 2019.

Getty Images 


\section{With the help of his backers}

and former Qaddafi officers,

Haftar has recruited thousands

of African mercenaries,

including Janjaweed and

diverse paramilitary and rebel

groups, offering $\$ 3,000$ plus

vehicles and plunder the UAE used its lobbying prowess to assist Haftar with the Trump Administration ${ }^{55}$ and attempted to control media in Libya. ${ }^{56}$ It deeply compromised the credibility of the United Nations by secretly hiring Bernardino Léon, the head of UNSMIL, as the highly remunerated director of its diplomatic academy while he was still leading negotiations. ${ }^{57}$ There are members of the U.S. Congress who feel the U.S. should cut off arms sales. $^{58}$

\section{Egypt}

have extra-marital relationships go to jail. Currently, there are reported to be a number of foreign female workers stuck in the UAE for this reason: the prisons will not take them because of COVID-19 but they are not allowed to leave until they serve their sentence. In the meantime, they and their children are in a precarious situation. ${ }^{50}$ However, it is not only poor women who have issues. A UK family court judgement found that that the emir of Dubai (also Vice-President and Prime Minister of the UAE) orchestrated the abductions of two of his daughters and subjected his youngest wife to a campaign of "intimidation." ${ }_{1}$ Though the UAE provided little help to Libya after the Revolution, it has been accused of arming Tubu tribal militias in the south since 2012. ${ }^{52}$ An early and important backer of Haftar's attempt to seize power, the UAE furnished financing and weapons and even carried out attacks using its own forces and weapons systems. ${ }^{53}$ It also paid for a number of mercenary forces to assist. ${ }^{54}$ Like Saudi Arabia,
Egypt is still a fairly conservative country where Sharia remains an important source of law. ${ }^{59}$ Recently, President el-Sisi has attempted to exert more control over religious authorities to serve his own interests. ${ }^{60}$ As head of the armed forces, he seized power in a coup against democratically elected President Mohammed Morsi from the Muslim Brotherhood following the Arab Spring. ${ }^{61}$ Some evidence purports to show that the UAE helped. ${ }^{62} \mathrm{~A}$ week after the coup, the UAE and Saudi Arabia gave $\$ 8$ billion to the new regime ${ }^{63}$ and have continued to provide substantial financing ever since. ${ }^{64}$ Much of this has helped pay for a massive increase in weapons purchases from France, which will be discussed in greater detail below. This financing has not been without cost, since Egypt's funders have expected to exercise a certain control over its affairs. ${ }^{65}$ Egypt gave two islands to Saudi Arabia ${ }^{66}$ and used its influence to block a motion to have the Saudi branch of ISIS added to a UN list of terrorist groups. ${ }^{67}$ Under 
President el-Sisi's leadership, Egypt has enthusiastically supported Haftar with weapons, air strikes, and fuel smuggling despite theoretically supporting the GNA. ${ }^{68}$ While paying lip service to peace negotiations, Egyptian materiel was simultaneously reported as on its way to Haftar when he began his assault days before the national dialogue was to begin ${ }^{69}$ and it also lobbied the Trump Administration on Haftar's behalf. ${ }^{70}$ While some of its air strikes purported to strike ISIS in response to attacks on Egyptian Coptic Christians living in Libya, they actually hit Libyan Salafists unrelated to the attacks but opposed to Haftar -the very ones who had forced ISIS out of Derna. ${ }^{71}$ Egypt's bad human rights record has not stopped France from cozying up to it, ${ }^{72}$ but it has led to calls by many in the U.S. to slash military aid after an American citizen was killed in prison there. ${ }^{73}$

\section{Russia}

Egypt has also been accused of housing Russian Special Forces ${ }^{74}$ and possibly other support elements aiding Haftar's campaign. From the beginning, Russia has tried to pretend to be neutral while providing material support for Haftar in the form of weapons systems, printing bank notes, and diplomatic cover. ${ }^{75}$ When Haftar's offensive on Tripoli stalled, reports appeared of 1,200 Russian mercenaries ${ }^{76}$ working for the Wagner Group, providing critical skills and eventually provoking Turkey's direct military engagement. ${ }^{77}$ These are similar to the fighters Russia sent to eastern Ukraine. ${ }^{78}$ Like the MENA autocracies, Moscow did not want a liberal democracy on its doorstep. In Libya, they have been accused of indiscriminately planting land mines leading to unnecessary civilian casualties. ${ }^{79}$ Russia is also alleged to have provided technicians, aircraft ${ }^{80}$ and air defense ${ }^{81}$ to support the Wagner mercenaries. This ally regularly conducts cyber-attacks in Europe and the rest of the world ${ }^{82}$ and is accused of trying to assassinate its critics, ${ }^{83}$ including women. ${ }^{84}$

\section{Ethnic Mercenaries}

With the help of his backers and former Qaddafi officers, Haftar has recruited thousands of African mercenaries, including Janjaweed and diverse paramilitary and rebel groups, offering \$3,000 plus vehicles and plunder. ${ }^{85}$ To a lesser extent, the GNA and/or other anti-Haftar groups have recruited some of their own fighters, mostly from Tubu groups along the border -but at times they are alleged to have tried to buy off some of Haftar's mercenaries. ${ }^{86}$ The Chadians and Sudanese are reputed to be good desert fighters: cheaper and more willing to work away from home. Besides money, they may have other motives like supporting their ethnic kin, trafficking, theft and other commercial interests. ${ }^{87}$ Groups have supported several factions as the situation or their motivations shifted. ${ }^{88}$ Brutal attacks by Haftar's forces on Tubu communities have been particularly motivating. ${ }^{89}$ The presence of these mercenaries not only helps sustain the Libyan conflict, it also destabilizes the region, which in turn creates more refugees. ${ }^{90}$ Libyans of 


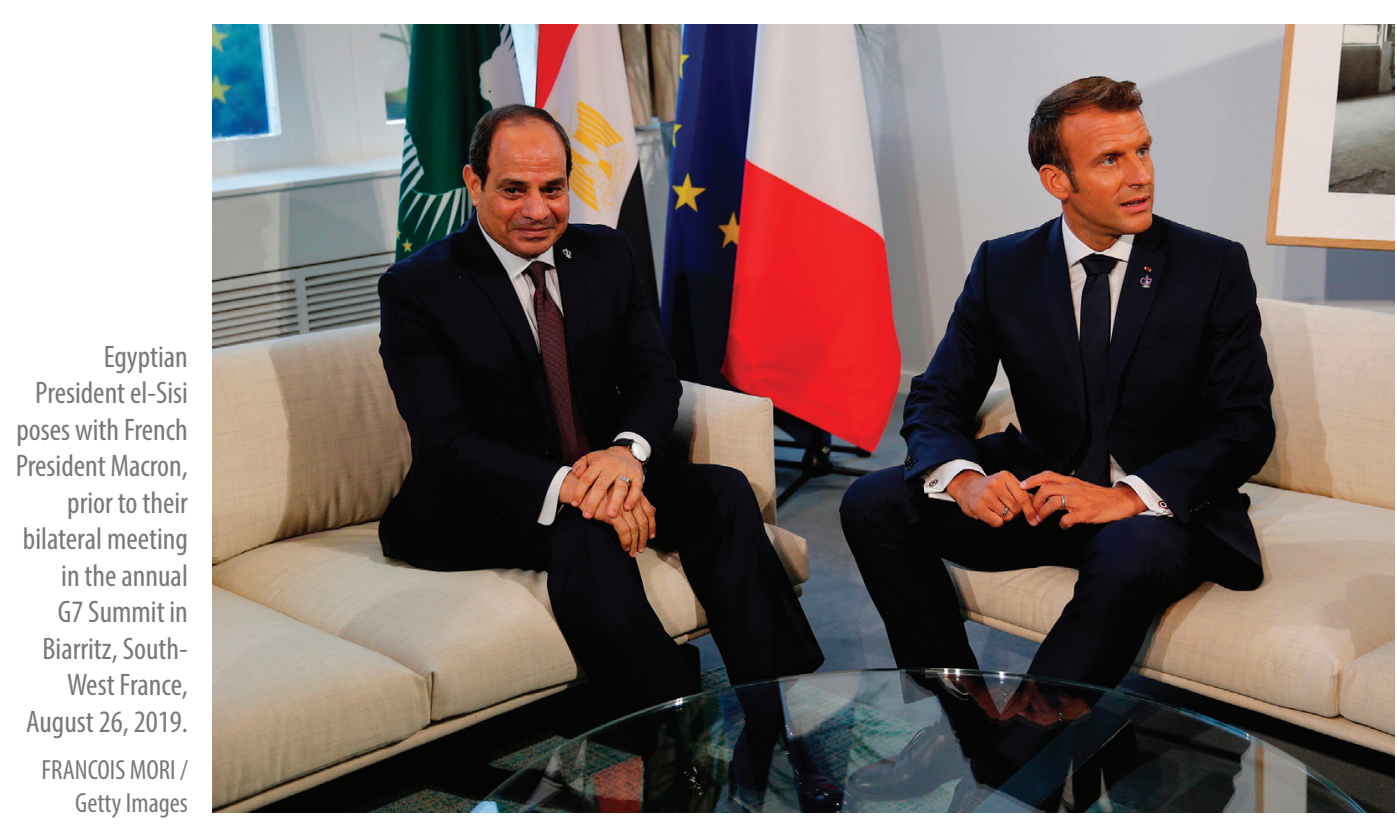

the same ethnicity as the mercenaries risk finding themselves identified as foreign fighters.

\section{"La France Perfide?"}

While Macron rails against Turkey for supporting the internationally recognized government of Libya against a rogue warlord accused of crimes against humanity, France has been actively assisting Haftar with special forces since at least early $2016 .{ }^{91}$ According to Haftar himself, "France helped (his cause) like no other country...providing information, military reconnaissance and security experts, which helped a lot." 92 Previously unacknowledged, this became overt when three French commandos were killed in July of 2016. ${ }^{93}$ The French advisers were accompanying Haftar forces fighting the local groups combating
ISIS. Their presence already indicated to many in the international community that France was keen to undermine the internationally recognized government in favor of a warlord. Apparently, mounting attacks against those actually fighting against ISIS is part of Macron's surreal anti-terrorist strategy. Under the direction of France's Directorate-General for External Security ${ }^{94}$ (DGSE), France has also employed mercenary outfits to aid Haftar with tasks such as crucial intelligence gathering, ${ }^{95}$ notably against the local Islamists who drove ISIS out of Derna. ${ }^{96}$ At the same time that France was assisting Haftar, the French-led Operation Barkhane has been accused by the UN Panel of Experts of refusing to share information with them. ${ }^{97}$ In 2019, U.S. Javelin missiles sold to France for use in Afghanistan were found in a Haftar camp captured by the GNA. ${ }^{98}$ 
An interview with Macron's Foreign Minister Le Drian after Haftar launched his offensive on Tripoli makes clear that the French government had no interest in a political solution. ${ }^{99}$ Macron has also used France's important positions in international organizations to shelter Haftar and stymie political discussions that might allow Libya to get out of its crisis in a more peaceful and sustainable way. In April 2019, France blocked an EU statement ${ }^{100}$ condemning Haftar's assault and teamed up with Russia to block a resolution calling for a ceasefire at the UN Security Council. ${ }^{101}$ There has also been controversy over the EU's "Operation Irini" (Eunavfor Med Irini) in the Mediterranean, which seeks to block weapons delivery by sea to Libya (i.e. mostly those going to the GNA) while doing nothing about all those shipped by its clients to Haftar by air or via Egypt. ${ }^{102}$ Related to that, there was an issue at NATO when France accused a Turkish frigate of harassing a French one trying to intercept a ship possibly carrying weapons to the GNA. Though the official NATO report was inconclusive, France quit Operation Sea Guardian in protest. ${ }^{103}$

\section{Refugees}

One of President Macron's reasons for supporting Haftar is that he believes the strongman will stop a flood of refugees washing up on the shores of the European Union. In this context, his hostility toward Turkey can only be explained as the complex of one who resents the person who does them a favor. Turkey is by far

\section{If its "champion" loses, then} France risks being frozen out, though it might hope that the regional autocracies would remember its efforts when making weapons purchases and other contracts

the country housing the world's largest refugee population, 3.6 million of whom are Syrians under temporary protection and close to 370,000 of which are refugees and asylum seekers of other nationalities. ${ }^{104}$ This is more than all the refugee populations of European Union member states combined $(2,591,349) .{ }^{105}$ Among Macron's autocratic friends: Egypt hosts about $258,816,{ }^{106}$ the UAE $1,247^{107}$ and Saudi Arabia 320. ${ }^{108}$ Saudi Arabia has agreed to allow some workers to continue their stay. ${ }^{109}$ France itself hosts around 407,923 refugees. ${ }^{110}$

\section{Blood Money}

What else can explain Macron and Le Drian's obsession with supporting Haftar? The most obvious and quantifiable explanation is the increasingly large number of weapons that France sells to autocracies in the MENA region. Given the misery, economic damage and ensuing flow of refugees that these have been causing, one might be forgiven for thinking this a short-sighted approach. However, one can understand the "après moi le déluge" attitude (i.e. a problem for 


\section{Though the behavior of}

\section{President Macron and his}

government may seem

hypocritical and somewhat

inspired by hysterical emotion,

there are certain elements of

commercial, short-term logic

to it his autocratic backers. The Near and Middle East represents almost half of France's total arms sales, which have been increasing exponentially over the last ten years. Egypt, Saudi Arabia and the UAE are all among France's biggest clients, each individually bigger than most other regions. The only other countries in the same league are India and Qatar. To further illustrate, Egypt and Saudi Arabia both bought more weapons from France last year than the rest of the European Union combined. Whether it wants to admit it or not, France has a powerful motivation to adopt the point of view of these important customers, which already feeds into some of its biases. If arms sales generate more chaos, then that will create more demand. The Macron government may even be tempted to throw in other services like training, information gathering, intelligence and the use of its vote in the Security Council and the EU. In 2009, France built its first new foreign base since the colonial period in Abu Dhabi, ostensibly to extend its strategic reach but also to help sell more weapons. ${ }^{113}$ Of course, the more France invests in this strategy, the more it will be tempted to double down, even when this may be a losing proposition. If Haftar wins, then it feels its oil investments will be secure and Haftar has promised big contracts for infrastructure ${ }^{114}$ plus, undoubtedly, more weapons sales. If its "champion" loses, then France risks being frozen out, though it might hope that the regional autocracies would remember its efforts when making weapons purchases and other contracts. 
Table 1: Details of Equipment Delivered Since 2010 by Country and Regional Breakdown (in Millions of Current $€$, 2010-2019)

\begin{tabular}{|c|c|c|c|c|c|c|c|c|c|c|c|}
\hline Country & 2010 & 2011 & 2012 & 2013 & 2014 & 2015 & 2016 & 2017 & 2018 & 2019 & Total \\
\hline Saudi Arabia & 697.6 & 380.5 & 418.9 & 418.6 & 643.7 & 899.8 & $1,085.8$ & $1,381.6$ & $1,398.8$ & $1,379.5$ & $8,704.8$ \\
\hline Bahrein & 9.8 & 26.8 & 76.7 & 3.0 & 0.9 & 3.1 & 3.4 & 1.5 & 2.0 & 0.1 & 127.2 \\
\hline Egypt & 39.6 & 9.8 & 27.5 & 63.6 & 103.0 & 1240.2 & 1329.6 & 1478.2 & 1276.3 & 1029.3 & $6,597.1$ \\
\hline $\begin{array}{c}\text { United Arab } \\
\text { Emirates }\end{array}$ & 257.9 & 271.1 & 185.8 & 274.0 & 126.8 & 293.6 & 399.9 & 226.8 & 237.0 & 287.2 & $2,560.1$ \\
\hline Iraq & 2.9 & 0.6 & 0.2 & 0.9 & 3.7 & 12.1 & 0.1 & 8.2 & 17.0 & 0.1 & 45.8 \\
\hline Israel & 35.2 & 20.5 & 11.0 & 15.0 & 14.0 & 19.5 & 30.2 & 18.1 & 22.1 & 22.7 & 208.3 \\
\hline Jordan & 0.8 & 0.7 & 0.6 & 0.6 & 0.6 & 1.6 & 1.0 & 2.7 & 3.6 & 0.6 & 12.9 \\
\hline Kuwait & 41.3 & 11.0 & 8.7 & 9.4 & 9.5 & 8.6 & 9.3 & 119.4 & 66.0 & 277.2 & 560.4 \\
\hline Lebanon & 0.6 & 1.5 & 0.4 & 9.2 & 9.7 & 3.0 & 0.3 & 3.5 & 3.0 & 0.5 & 31.6 \\
\hline Oman & 221.1 & 123.1 & 222.9 & 110.1 & 85.6 & 32.0 & 90.1 & 105.4 & 29.8 & 43.7 & $1,063.9$ \\
\hline Qatar & 36.9 & 37.0 & 122.7 & 20.3 & 46.5 & 134.7 & 116.1 & 137.2 & 164.3 & $3,330.6$ & $4,146.2$ \\
\hline Yemen & 0.7 & - & - & - & - & - & - & - & - & - & 0.7 \\
\hline $\begin{array}{l}\text { Total Near and } \\
\text { Middle East }\end{array}$ & $1,344.5$ & 882.6 & $1,075.6$ & 924.7 & $1,043.8$ & $2,648.3$ & $3,065.5$ & $3,482.6$ & $3,219.9$ & $6,371.6$ & $24,059.1$ \\
\hline $\begin{array}{l}\text { Total North- } \\
\text { East Asia }\end{array}$ & 137.3 & 153.8 & 168.6 & 222.1 & 194.1 & 204.6 & 229.2 & 219.2 & 244.5 & 260.2 & $2,033.5$ \\
\hline $\begin{array}{c}\text { Total Central } \\
\text { Asia }\end{array}$ & 8.6 & 5.3 & 7.6 & 33.5 & 1.9 & 211.6 & 158.4 & 19.5 & 90.2 & 24.0 & 560.6 \\
\hline $\begin{array}{c}\text { Total South } \\
\text { Asia }\end{array}$ & 374.3 & 298.1 & 284.0 & 454.4 & 511.7 & $1,139.5$ & $1,046.9$ & 764.5 & 707.6 & 845.2 & $6,426.3$ \\
\hline $\begin{array}{l}\text { Total South- } \\
\text { East Asia }\end{array}$ & 190.1 & 130.8 & 369.8 & 488.6 & 263.9 & 456.1 & 419.5 & 392.7 & 552.3 & 316.0 & $3,579.9$ \\
\hline $\begin{array}{l}\text { Total North } \\
\text { America }\end{array}$ & 203.6 & 317.2 & 115.6 & 166.0 & 170.2 & 146.4 & 163.1 & 181.2 & 252.9 & 480.6 & $2,196.9$ \\
\hline $\begin{array}{l}\text { Total Central } \\
\text { America and } \\
\text { Caribbean }\end{array}$ & 30.7 & 55.1 & 206.4 & 58.7 & 112.2 & 3.2 & 33.5 & 93.6 & 69.0 & 0.9 & 663.1 \\
\hline $\begin{array}{c}\text { Total South } \\
\text { America }\end{array}$ & 133.7 & 180.6 & 206.3 & 512.3 & 148.2 & 191.5 & 416.3 & 407.5 & 521.4 & 362.5 & $3,080.4$ \\
\hline $\begin{array}{l}\text { Total North } \\
\text { Africa }\end{array}$ & 307.9 & 240.5 & 40.3 & 57.3 & 495.2 & 54.1 & 245.5 & 102.5 & 174.9 & 125.2 & $1,843.4$ \\
\hline $\begin{array}{l}\text { Total Sub- } \\
\text { Saharan } \\
\text { Africa }\end{array}$ & 53.5 & 125.2 & 29.2 & 67.4 & 33.1 & 62.0 & 90.8 & 50.6 & 146.3 & 261.3 & 919.4 \\
\hline Total Oceania & 158.5 & 223.8 & 225.8 & 111.4 & 155.8 & 140.6 & 187.7 & 70.1 & 86.7 & 107.9 & $1,468.4$ \\
\hline $\begin{array}{l}\text { Total Other } \\
\text { European } \\
\text { Countries }\end{array}$ & 157.1 & 188.4 & 153.5 & 167.5 & 135.9 & 216.1 & 145.4 & 171.4 & 170.1 & 112.6 & $1,618.1$ \\
\hline $\begin{array}{c}\text { Total } \\
\text { European } \\
\text { Union }\end{array}$ & 604.0 & 845.9 & 461.5 & 516.9 & 580.8 & 587.0 & 779.2 & 688.0 & 644.9 & 567.1 & $6,275.3$ \\
\hline $\begin{array}{c}\text { Diverse } \\
\text { (International } \\
\text { Organization, } \\
\text { Non-UN } \\
\text { Member } \\
\text { States) } \\
\end{array}$ & 79.1 & 130.9 & 35.0 & 99.8 & 198.8 & 140.3 & 140.1 & 87.5 & 85.2 & 90.7 & $1,087.3$ \\
\hline Total & $3,783.0$ & $3,778.2$ & $3,379.1$ & $3,880.6$ & $4,045.4$ & $6,201.5$ & $7,121.0$ & $6,730.9$ & $6,966.0$ & $9,925.8$ & $55,811.5$ \\
\hline
\end{tabular}

Source: French Ministry of Armed Forces

Despite the criticisms of French arms sales to these countries by institutions like the European Parliament, ${ }^{115}$ Amnesty International ${ }^{116}$ and Human
Rights Watch, ${ }^{117}$ President Macron probably feels that because he has a female defense minister in charge of these transactions (Florence Parly), 
that they are consistent with a "feminist foreign policy."

\section{Conclusion}

France has based its fervent support for Libyan warlord Khalifa Haftar in the name of fighting Islamic terrorism, which it conflates with political Islam. While claiming to pursue a "feminist foreign policy," it has ignored the many crimes against humanity attributed to Haftar's coalition and the repressive policies of his international backers. It also seeks to minimize the numbers of refugees coming to Europe. Though somehow resentful towards Turkey for hosting millions that might otherwise come to France, it seems oblivious to the way its own actions help create the conditions that produce refugees. Though the behavior of President Macron and his government may seem hypocritical and somewhat inspired by hysterical emotion, there are certain elements of commercial, short-term logic to it; notably, the sale of weapons. Unfortunately, besides the destruction of its credibility, France's policies will likely cause harm not only to Africa and the Middle East, which they are doing already, but also to France and Europe.

\section{Endnotes}

1. Paul Taylor, "France's Double Game in Libya: In Backing a Warlord, Paris May Be Dealing Itself a Losing Hand," Politico, (April 19, 2019).

2. Dirk Vandewalle, A History of Modern Libya, $2^{\text {nd }}$ Edition, (Cambridge, MA: Cambridge University Press, 2012).
3. Bernard-Henri Lévy, La Guerre Sans L'aimer: Journal d'un Écrivain au Cour du Printemps Libyen, (Grasset, 2011).

4. "Remarks by President Obama to the United Nations General Assembly," The White House Office of the Press Secretary, (September 28, 2015).

5. Crispin Blunt, “Government 'Unwilling' to Learn the Lessons of Libya Interventions," UK House of Commons, (November 25, 2016).

6. Acil Tabbara, "Le Maréchal Haftar, Émule de Kadhafi?," L'Orient-Le Jour, (February 17, 2018); Jérôme Tubiana and Claudio Gramizzi, "Lost in Trans-Nation: Tubu and Other Armed Groups and Smugglers along Libya's Southern Border," Small Arms Survey, (December 2018).

7. Mark Urban, "The Task of Forming a more Effective Anti-Gaddafi Army," BBC News, (April 15, 2011).

8. "Attempted Coup d'état in Libya," Voltaire Network, (February 15, 2014); "S/2015/128 - Final Report of the Panel of Experts on Libya Established Pursuant to Security Council Resolution 1973 (2011),"United Nations, Distr. General, (February 23, 2015), Paragraph 32; "Libya Major General Khalifa Haftar Claims Gov't Suspended in Apparent Coup Bid; PM Insists Tripoli 'Under Control,"' CBS News, (February 14, 2014).

9. Also referred to as the "Libyan Arab Armed Forces" (LAAF) or in the parlance of the UN Panel of Experts on Libya: Haftar Armed Forces (HAF).

10. The group is also commonly referred to as the Islamic State of Iraq and the Levant (ISIL), which is way it is usually referred to in United Nations documents, as well as the Islamic State (IS) or "Daesh" in Arabic (sometimes spelled "Daech" with a c instead of an s).

11. Dan De Luce, "Why Libya Matters-Again: The Islamic State Is Gaining Ground in Libya's Chaotic Vacuum and Western Governments Are Worried," Foreign Policy, (February 12, 2016).

12. Against this background, Haftar was able to gain a political role and the legitimacy such role requires by presenting himself as the leader in fighting Islamic terrorism and the emergence of radical groups in Libya. See Karim Mezran, and Arturo Varvelli, "Libyan Crisis: International Actors at Play" in Karim Mezranv and Arturo Varvelli (eds), Foreign Actors in Libya's Crisis, (Atlantic Council and Italian Institute for International Political Studies (ISPI), 2017), p. 16. Indeed, it is this image of Haftar as a fighter of "Islamic terrorism" that the UAE and Saudi Arabia were able to sell to President Trump and which led to his dubious praise for Haftar even after he had started 
his advance on Tripoli days before the Libyan peace conference was due to begin in April 2019. Though he did not officially endorse the offensive as such, in the phone call he had with Haftar, it was reported that Trump "recognised Field Marshal Haftar's significant role in fighting terrorism and securing Libya's oil resources, and the two discussed a shared vision for Libya's transition to a stable, democratic political system." See, "Trump Discussed 'Shared Vision' in Phone Call to Libyan Warlord Haftar," France 24, (April 19, 2019).

13. Mary Fitzgerald and Mattia Toaldo, "A Quick Guide to Libya's Main Players," European Council on Foreign Relations, (December 2016).

14. "S/2018/140-United Nations Support Mission in Libya Report of the Secretary-General," United Nations Security Council, (February 12, 2018), Paragraph 14; "A Quick Guide to Libya's Main Players; Christopher M. Blanchard and Carla E. Humud, "The Islamic State and U.S. Policy," US Congressional Research Service, (January 18, 2017), p. 22.

15. Emma Graham-Harrison and Chris Stephen, "Libyan Forces Claim Sirte Port Captured from ISIS as Street Battles Rage," The Guardian, (June 11, 2016); Tom Westcott and Mark Hookham, "SAS Blasts ISIS with 'Punisher' in Libya," The Sunday Times, (August 7, 2016); Missy Ryan and Sudarsan Raghavan, "U.S. Special Operations troops aiding Libyan Forces in Major Battle against Islamic State," The Washington Post, (August 9, 2016). It is possible that the UK forces included participation from Jordanian Special Forces as well. See, Rori Donaghy, "Revealed: Britain and Jordan's Secret War in Libya," Middle East Eye, (March 25, 2016).

16. "AFRICOM Concludes Operation Odyssey Lightning," United States Africa Command, (December 2, 2016).

17. "S/2016/1011-United Nations Support Mission in Libya Report of the Secretary-General," United Nations Security Council, (December 01, 2016), Paragraphs 22-25.

18. "S/2019/19-United Nations Support Mission in Libya Report of the Secretary-General," United Nations Security Council, (January 7, 2019), Paragraph 74.

19. "One Year of Destructive War in Libya, UNSMIL Renews Calls for Immediate Cessation of Hostilities and Unity to Combat COVID-19," UNSMIL, (April 4, 2020).

20. Because of the conflict, according to a survey by the World Health Organization (WHO), while 75 percent of primary health centers are open, only 20 percent are delivering services. See, "Act- ing SRSG Stephanie Williams Briefing to the Security Council," UNSMIL, (May 19, 2020).

21. "S/2018/140,"Paragraphs 50 and 81 ; "S/2019/ 682-United Nations Support Mission in Libya Report of the Secretary-General," United Nations Security Council, (August 26, 2019). Paragraphs 5758; "S/2020/41-United Nations Support Mission in Libya Report of the Secretary-General," United Nations Security Council, (January 15, 2020), Paragraph 54.

22. "S/2019/682," Paragraph 57.

23. "S/2020/41," Paragraph 54.

24. "Acting SRSG Stephanie Williams Briefing to the Security Council."

25. Karina Piser, "Macron Wants to Start an Islamic Revolution: The French President is Planning to Curb the Influence of Extremist Clerics-But His Critics See Something More Sinister," Foreign Policy, (October 7, 2020).

26. "Stopping the War for Tripoli: Middle East and North Africa," International Crisis Group, (May 23, 2019), especially note 37; Jalel Harchaoui, "How France Is Making Libya Worse: Macron Is Strengthening Haftar," Foreign Affairs, (September 21, 2017).

27. David D. Kirkpatrick, "Russian Snipers, Missiles and Warplanes Try to Tilt Libyan War," The New York Times, (November 5, 2019); Michele Dunne, "Support for Human Rights in the Arab World: A Shifting and Inconsistent Picture," Carnegie Endowment for International Peace, (December 28, 2018); Wolfram Lacher and Alaa al-Idrissi, "Capital of Militia: Tripoli's Armed Groups Capture the Libyan State," Small Arms Survey, (June 2018).

28. "Stopping the War for Tripoli."

29. Keith Johnson and Robbie Gramer, "How the Bottom Fell Out of the U.S.-Saudi Alliance," Foreign Policy, (April 23, 2020).

30. Kareem Chehayeb, "Saudi Arabia's Biggest Obstacle to Progress Lies in Its Systematic Human Rights Violations," Amnesty International, (January 30, 2018).

31. "Saudi Arabia: 'Image Laundering' Conceals Abuses: New Human Rights Watch Campaign Against Whitewashing Rights Violations," Human Rights Watch, (October 2, 2020).

32. Former Soviet Union intelligence agency, Komitet Gosudarstvennoy Bezopasnosti, which translates to "Committee for State Security" in English.

33. The UK Government started to look into the deal but was blocked by the courts who said that 
the investigation was not done soon enough. See, Jim Waterson, "Court Blocks Inquiry into Independent and Standard's Links to Saudi Arabia," The Guardian, (August 16, 2019).

34. Luke Harding and Dan Sabbagh, "Johnson Visit to Lebedev Party after Victory Odd Move for 'People's PM,'” The Guardian, (December 22, 2019).

35. Ben Hubbard, "After a Year of Silence, a Jailed Saudi Princess Appeals for Help," The New York Times, (April 17, 2020).

36. Adela Suliman, "Saudi G20 Event Slammed over Kingdom's Treatment of Women," NBC News, (October 26, 2020).

37. This is the official spelling used by the United Nations. Also spelled as "Al-Qaeda."

38. Named after Sheikh Rabee al-Madkhali, a Saudi theologian whose followers adhere to an ultra-conservative but politically quietist ideology. See, "Addressing the Rise of Libya's MadkhaIi-Salafis: Middle East and North Africa," International Crisis Group, (April 25, 2019).

39. "Rabei al-Madkhali Calls for a Salafi Revolution against the "Brotherhood" in Libya," Arabi 21, (July 9, 2016).

40. Frederic Wehrey, "Quiet No More? 'Madkhali' Salafists in Libya are Active in the Battle against the Islamic State, and in Factional Conflicts," Carnegie Middle East Center, (October 13, 2016); Lacher and al-Idrissi, "Capital of Militia: Tripoli's Armed Groups Capture the Libyan State;" "Addressing the Rise of Libya's Madkhali-Salafis."

41. Francesca Mannocchi, "Saudi-Influenced Salafis Playing Both Sides of Libya's Civil War," Middle East Eye, (December 11, 2018).

42. Vivian Salama, Jared Malsin, and Summer Said, "Trump Backed Libyan Warlord after Saudi Arabia and Egypt Lobbied Him," The Wall Street Journal, (May 12, 2019).

43. "Stopping the War for Tripoli," Paragraph 21; Jared Malsin and Summer Said, "Saudi Arabia Promised Support to Libyan Warlord in Push to Seize Tripoli," The Wall Street Journal, (April 12, 2019); Tim Lister, "Battle for Tripoli Becomes a Sandbox for Outside Powers," CNN, (May 7, 2019); Samuel Ramani, "Saudi Arabia Steps Up Role in Libya," Al-Monitor, (February 24, 2020).

44. "Why Is Saudi Arabia Funding Russian "Wagner" Mercenaries to Kill Libyans?" Arraed LG, (January 26, 2020); Ramani, "Saudi Arabia Steps up Role in Libya."

45. Johnson and Gramer, "How the Bottom Fell Out of the U.S.-Saudi Alliance."
46. "European Parliament Urges Arms Embargo on Saudi Arabia," Amnesty International, (October 25, 2018).

47. "Campaign against Arms Trade vs. The Secretary of State for International Trade [CAAT -vSSIT]," EWCA Civ 1020, (2019).

48. Jessica Murray, "UK Faces New Legal Challenge over Arms Sales to Saudi Arabia," The Guardian, (October 27, 2020).

49. "UNHCR Operational Update for Yemen," UN$H C R$, (September 10, 2020).

50. Katie McQue, "'They Have to Be Punished:'The Mothers Trapped in the UAE by 'Love Crimes,"' The Guardian, (October 12, 2020).

51. Owen Bowcott and Haroon Siddique, "Dubai Ruler Organised Kidnapping of His Children, UK Court Finds," The Guardian, (March 5, 2020).

52. Tubiana and Gramizzi, "Lost in Trans-Nation."

53. "S/2019/914 - Final report of the Panel of Experts on Libya established pursuant to Security Council Resolution 1973," (2011) United Nations, Distr. General, December 9, 2019, Paragraphs 61, 62, 72-75, 96-97, 104, 108-110, Annexes 15, 32, 39, $40,46,47,51,52$; ${ }^{\prime} S / 2018 / 812$ - Final report of the Panel of Experts on Libya Established Pursuant to Resolution 1973 (2011)," United Nations:, Distr. General (5 September 2018), Paragraphs 75-76, 92-97 and Annexes 30 and 33; "S/2017/466 - Final report of the Panel of Experts on Libya established pursuant to Security Council Resolution 1973 (2011)," United Nations, Distr. General (June 1, 2017), Paragraphs 120-128, 132, 160-163, and Annexes 34, 35, 38, 48; "S/2016/209 - Final report of the Panel of Experts on Libya established pursuant to Security Council Resolution 1973 (2011)," United Nations, Distr. General (March 9, 2016), Paragraphs 27, 111-113, 117-119, 130-131, 140-143, 240 and Annexes 23, 26, 27, 29, 30, 35; "S/2015/128," Paragraphs 60, 125-131, 172-174 and Annex 18; "Stopping the War for Tripoli;" Oscar Nkala, “UAE Donates Armored Personnel Carriers, Trucks to Libya," Defense News, (April 28, 2016); Jared Malsin, "U.S.-Made Airplanes Deployed in Libya's Civil War, in Defiance of U.N.," Time Magazine, (May 9, 2017); Jared Malsin, "U.A.E. Boosted Arms Transfers to Libya to Salvage Warlord's Campaign, U.N. Panel Finds," The Wall Street Journal, (September 29, 2020).

54. Rabia Golden, "Sudanese Mercenaries Train in the UAE Prior to Deployment in Libya," Libya Observer, (May 3, 2020); "CAE Aviation, Joker Décisif de Macron et Haftar à Derna," Africa Intelligence, (May 31, 2018); "Prince à la Rescousse des Émirats 
en Libye," Intelligence Online, (January 11, 2017); "Riccardo Mortara Muscle les Forces Aériennes de Haftar," Africa Intelligence, (May 17, 2018); "L'aviation Émiratie est là pour Rester," Africa Intelligence, (January 26, 2017); Malsin and Said, "Saudi Arabia Promised Support to Libyan Warlord in Push to Seize Tripoli."

55. David D. Kirkpatrick, "The Most Powerful Arab Ruler Isn't M.B.S. It's M.B.Z.," The New York Times, (June 2, 2019); "UAE Inciting US to Intervene in Libya," Middle East Monitor, (July 1, 2020).

56. Abdelkader Assad, “UAE, Saudi Arabia Aiding Libya Eastern Forces, Blacklisting Qatar for Alleged Support for Other Libyans," Libya Observer, (June 13, 2017).

57. "S/2016/209," Paragraph 24 and Annex 30; David D. Kirkpatrick, "Leaked Emirati Emails Could Threaten Peace Talks in Libya," The New York Times, (November 12, 2015); Wolfram Lacher, Libya's Fragmentation: Structure and Process in Violent Conflict (London and New York: I.B. Tauris, 2020), p. 45.

58. Brian Dooley, "How the United Arab Emirates Contributes to Mess after Mess in the Middle East," The Washington Post, (July 9, 2019); Kirkpatrick, "The Most Powerful Arab Ruler Isn't M.B.S. It's M.B.Z."

59. According to Article 2: Islam, Principles of Islamic Sharia of the 2014 Constitution [unchanged from previous versions]: Islam is the religion of the state and Arabic is its official language. The principles of Islamic Sharia are the principle source of legislation. "Egypt's Constitution of 2014," Constituteproject.org, (August 27, 2020).

60. "Egypt's al-Azhar Poised to be stripped of its power," Middle East Eye, (July 24, 2020).

61. François Brousseau, "L'Égypte Totalitaire," Le Devoir, (February 18, 2019).

62. David D. Kirkpatrick, "Recordings Suggest Emirates and Egyptian Military Pushed Ousting of Morsi," The New York Times, (March 1, 2015).

63. Robert F. Worth, "Egypt is Arena for Influence of Arab Rivals," The New York Times, (July 9, 2013).

64. "Gulf Countries Supported Egypt with \$92bn since 2011," Middle East Monitor, (March 19, 2019).

65. David Hearst, "The Emirati plan for ruling Egypt," Middle East Eye, (November 23, 2015).

66. Mohamad Elmasry, "Egypt: Seven Years after the Coup, Repression Reigns as the Economy Tanks," Middle East Eye, (July 1, 2020).
67. Olivia Alabaster, “Egypt Blocked UN Sanctions against Saudi Branch of Islamic State," Middle East Eye, (July 6, 2017).

68. "S/2019/914," Paragraphs 106, 72-75 and Annexes 15, 32, 44; "S/2018/812," Paragraph 106; "S/2017/466," Paragraphs 186-187 and Annexes 41 and 68; "S/2016/209," Paragraphs 55, 133-137, 144-146, 179, 241, 247 and Annexes 28 and 36; "S/2015/128," Paragraphs 167-171 and Annex 24; "Stopping the War for Tripoli."

69. "Averting a Full-blown War in Libya," International Crisis Group, (April 10, 2019).

70. Salama, Malsin, and Said, "Trump Backed Libyan Warlord after Saudi Arabia and Egypt Lobbied Him."

71. Ahmed Aboulenein and Giles Elgood, "Is Egypt Bombing the Right Militants in Libya?" Reuters, (May 31, 2017)

72. Shaul Shay, "Egypt, France Conclude Joint Naval Exercise," Israel Defense, (July 16, 2017); Lénaïg Bredoux, "La France Plus Amie que Jamais avec la Dictature Militaire Égyptienne," Médiapart, (June 9, 2017).

73. See for example, Jack Detsch, Robbie Gramer, and Colum Lynch, "After Death of U.S. Citizen, State Department Floats Slashing Egypt Aid," Foreign Policy, (March 31, 2020); Brousseau, "L'Égypte Totalitaire."

74. Phil Stewart, Idrees Ali, and Lin Noueihed, “Exclusive: Russia Appears to Deploy Forces in Egypt, Eyes on Libya Role -Sources," Reuters, (March 13, 2017); "Des forces Spéciales Russes en Égypte, près de la Libye, Révèle un Responsable Américain," L'Orient-Le Jour, (March 14, 2017).

75. "S/2019/914," Paragraphs 92, 131-132 and Annexes 37, 38, and 51; "S/2018/812," Paragraphs 75-76, 92-97 and Annexes 30 and 33; "S/2017/466," Paragraphs 170, 213 and Annexes 35 and 43; "S/2016/209," Paragraphs 164 and 167; "S/2015/128," Paragraph 164; "Stopping the War for Tripoli."

76. This has supposedly been confirmed by the UN Panel of Experts. The Report has not been made public yet, since Russia has blocked its publication, but several news agencies have seen copies of it and the topic has been referenced by other UN agencies such as the Working Group on the use of mercenaries. See, David Wainer, "Russian Mercenaries Act as 'Force Multiplier' in Libya, UN Says," Bloomberg, (May 5, 2020); “UN Monitors Say Mercenaries from Russia's Vagner Group Fighting in Libya," Radio Free Europe, (May 7, 2020); "Russian Group's 1,200 Mercenaries Fighting in 
Libya: UN report," Al Jazeera, (May 7, 2020); David D. Kirkpatrick and Declan Walsh, "As Libya Descends into Chaos, Foreign Powers Look for a Way Out," The New York Times, (January 18, 2020); Wolfram Lacher, "International Schemes, Libyan Realities: Attempts at Appeasing Khalifa Haftar Risk Further Escalating Libya's Civil War," SWP, (November 2019); "Why Is Saudi Arabia Funding Russian "Wagner" Mercenaries to Kill Libyans?; "Soldiers of Misfortune - Why African Governments Still Hire Mercenaries," The Economist, (May 30, 2020); For the statement by the UN Working Group on the use of mercenaries, see: "Libya: Violations related to mercenary activities must be investigated - UN Experts," Office of the High Commissioner for Human Rights, (June 17, 2020); “S/2020/421 Statement by the Acting Special Representative of the Secretary-General and Head of the United Nations Support Mission in Libya, Stephanie Williams," United Nations, (May 21, 2020). A figure of 3,000 was mentioned by an American diplomat in an International Crisis Group Report; see, "Turkey Wades into Libya's Troubled Waters," International Crisis Group, No. 257 (April 30, 2020), p. 3, note 7.

77. "Turkey Wades into Libya's Troubled Waters."

78. "Syria War: Who Are Russia's Shadowy Wagner Mercenaries?," BBC, (February 23, 2018).

79. Samy Magdy, "US Africa Command: Russian Mercenaries Planted Land Mines in Libya," The Associated Press, (July 15, 2020).

80. Andrew England, Heba Saleh, Henry Foy, and Laura Pitel, "UN Experts Probe Dispatch of Russian-Made Warplanes to Libya," Financial Times, (May 21, 2020).

81. "Les Pantsir de Moscou à la Rescousse d'Haftar," Intelligence Online, (December 24, 2019).

82. Katrin Bennhold, "Germany Wants E.U. to Sanction Head of Russian Military Intelligence," The New York Times, (May 28, 2020); "NSA: Russian Agents Have Been Hacking Major Email Program," Security Week, (May 28, 2020).

83. Robyn Dixon, "Inside Room 239: How Alexei Navalny's Aides Got Crucial Poisoning Evidence out of Russia," The Washington Post, (October 4, 2020); David Filipov, "10 Critics of Vladimir Putin who Wound Up Dead," Chicago Tribune, (March $25,2017)$.

84. Shaun Walker, "The Murder That Killed Free Media in Russia," The Guardian, (October 5, 2016); Lana Estemirova, "My Mum and Anna Politkovskaya: Women who Died for the Truth," The Guardian, (October 5, 2016).
85. "S/2019/914," Paragraphs 19, 27, 29, 31-33 and Annex 9; "S/2018/812," Paragraph 24 and Annexes 9 and 10; "S/2017/466," Paragraphs 83-86 and Annex 23; "S/2016/209," Paragraphs 28, 30, 68-69; Tubiana and Gramizzi, "Lost in Trans-Nation;"Wolfram Lacher, "Who is Fighting Whom in Tripoli?", Small Arms Survey, (August 2019); "Stopping the War for Tripoli;" Golden, "Sudanese Mercenaries Train in the UAE Prior to Deployment in Libya."

86. $\mathrm{S} / 2019 / 914$, paragraphs 19, 28-30, 32-33; "S/2018/812," Paragraphs 22 and 24 and Annex 9; "S/2017/466," Paragraphs 84 and 85 and Annex 23; Tubiana and Gramizzi, "Lost in Trans-Nation."

87. "S/2017/466," Paragraphs 79 and 83; Tubiana and Gramizzi, "Lost in Trans-Nation."

88. "S/2018/812," Paragraphs 22 and 24 and Annex 9; Tubiana and Gramizzi, "Lost in Trans-Nation," p. 14;

89. “S/2019/914," Annex 16.

90. "S/2017/466," Paragraph 86 and Annex 23; "S/2016/209," Paragraphs 27, 27, 67, 177; "S/2015/128," Paragraph 204; Tubiana and Gramizzi, "Lost in Trans-Nation."

91. Nathalie Guibert, "La Guerre Secrète de la France en Libye," Le Monde, (February 23, 2016); Taylor, "France's Double Game in Libya."

92. See, "Le Maréchal Haftar, à la Tête de L'armée Libyenne: 'C'est aux Libyens de Décider ce qui est Bon pour eux," Le Journal du Dimanche, (February 4, 2017- updated June 21, 2017).

93. "S/2017/466," Paragraph 133; "Ce n'est plus un Secret, la France est Militairement Présente en Libye," L'Obs (Avec AFP), (July 20, 2016); Inti Landauro and Hassan Morajea, "Three French Special Forces Soldiers Killed in Helicopter Crash in Libya," Wall Street Journal, (July 20, 2016); Cyril Bensimon, Frédéric Bobin, and Madjid Zerrouky, "Trois Membres de la DGSE Morts en Libye," Le Monde, (July 20, 2016).

94. Direction Générale de la Sécurité Extérieure.

95. "Intelligence: Paris Deploys CAE Aviation to Keep Watch over Turkish Arms Supplies to Libya," Africa Intelligence.

96. "CAE Aviation, Joker Décisif de Macron et Haftar à Derna;" "La DGSE aux Premières Loges de L'offensive de Haftar sur Derna," Africa Intelligence, (June 7, 2018).

\section{7. "S/2016/209," Paragraph 177.}

98. France claimed that they were for the selfprotection of its teams working in Libya. See, "S/2019/914," Paragraph 93; "L'embarras de Paris 
après la Découverte de Missiles sur une Base d'Haftar en Libye," Le Monde, (July 10, 2019); Lacher, "International Schemes, Libyan Realities."

99. Jean-Yves Le Drian, "La France est en Libye pour Combattre le Terrorisme," Ministry of Europe and Foreign Affairs, (May 2, 2019); Andrew England, "Libya: How Regional Rivalries Fuel the Civil War," Financial Times, (February 25, 2020).

100. Gabriela Baczynska and Francesco Guarascio, "France Blocks EU Call to Stop Haftar's Offensive in Libya," Reuters, (April 10, 2019); "EU, France Split on Libya as Khalifa Haftar Strikes Tripoli," Deutsche Welle, (April 23, 2019).

101. "Stopping the War for Tripoli," pp. 8-10.

102. "Turkey Wades into Libya's Troubled Waters."

103. Robin Emmott, John Irish, and Tuvan Gumrukcu, "NATO Keeps France-Turkey Probe under Wraps as Tempers Flare," Reuters, (September 17, 2020); “Des Frégates Turques Menacent un Navire Français en Méditerranée," Le Point, (June 17, 2020); "La France Suspend sa Participation à une Opération de I'OTAN en Méditerranée après des Tensions avec la Turquie," Le Monde (avec AFP), (July 1, 2020).

104. "UNHCRTurkey-FactSheetSeptember2020," UNHCR, (2020). Turkey had 3,579,531 refugees and 328,257 asylum seekers, see, "Global Trends Forced Displacement In 2019," UNHCR, (2019).

105. "Refugee Population by Country or Territory of Asylum," The World Bank.

106. "UNHCR Egypt-Fact Sheet July 2020," UN$H C R$, (July 2020).

107. The "Global Trends Forced Displacement in
2019" notes another 7,270 asylum seekers (pending cases).

108. The "Global Trends Forced Displacement in 2019" notes another 2,331 asylum seekers (pending cases).

109. "Saudi Arabia Says Criticism of Syria Refugee Response 'False and Misleading," The Guardian, (September 12, 2015).

110. "Global Trends Forced Displacement in 2019." The same report lists another 102,157 asylum seekers (cases pending).

111. "Conventional Arms Transfers to Developing Nations, 2008-2015," U.S. Congressional Research Service.

112. "Rapport au Parlement 2019 sur les exportations d'armement de la France," French Ministry of the Armed Forces, (June 2, 2020).

113. "Inauguration de la base d'Abu Dhabi," French Ministry of the Armed Forces, (April 12, 2018), retrieved from https://t.ly/NVG8; Matthew Saltmarsh, "France Opens First Military Bases in the Gulf," The New York Times, (May 26, 2009).

114. "Le Maréchal Haftar, à La Tête de L'armée Libyenne."

115. "European Parliament Urges Arms Embargo on Saudi Arabia."

116. "Egypt: How French Arms Were Used to Crush Dissent," Amnesty International, (October 16, 2018).

117. Bruno Stagno Ugarte, "Macron's Selective Indignation over Libya: Void between Words and Deeds Harms French Credibility and Fight against Impunity," Human Rights Watch, (July 17, 2020). 


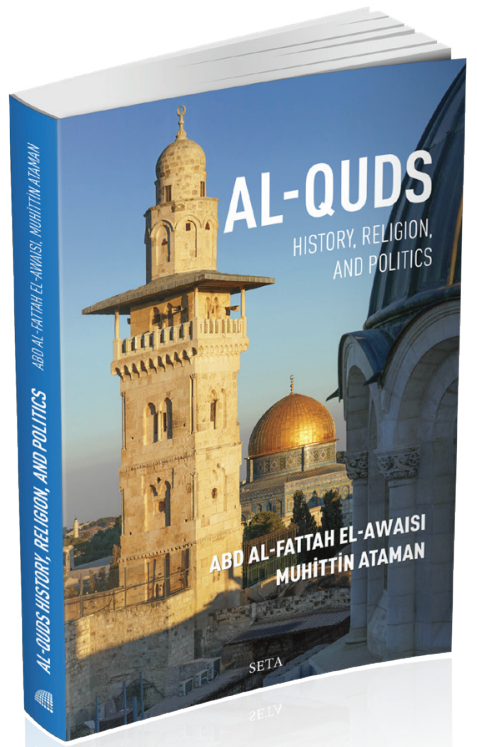

\section{Al-Quds | History, Religion and Politics}

September 2019 | Abd al-Fattah El-Awaisi, Muhittin Ataman

Considering the transformation process in the Middle East and the global transition, it is clear that the Palestinian-Israeli question and the issue of al-Quds will continue to dominate the agenda of the Middle East and global system. Recent regional developments such as Trump's decision regarding the future of Jerusalem and the solution proposal called the "Deal of Century" by the Trump Administration demonstrate that the holy city of al-Quds will continue.

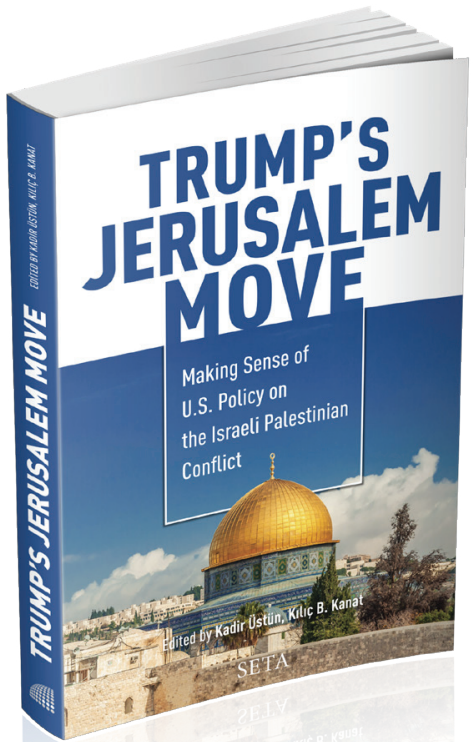

\section{Trump's Jerusalem Move}

April 2020| Kadir Üstün, Kılıç Buğra Kanat

This critically important book includes chapters both contextualizing and discussing the U.S. administration's Jerusalem declaration in great detail. Various sections authored by American, Latin American, European, and Turkish authors examine the international responses to the U.S. President Trump's declaration. 